\title{
A new burmagomphid dragonfly from the Eocene of Patagonia, Argentina
}

\author{
Julián F. Petrulevičius \\ Acta Palaeontologica Polonica 62 (4), 2017: 779-783 doi:https://doi.org/10.4202/app.00427.2017
}

A new burmagomphid anisopteran, Satelitala soberana gen. et sp. nov. is described from the lower Eocene of Laguna del Hunco, Patagonia, Argentina. The new genus is characterised by hindwing characters such as the subdiscoidal triangle not elongated; anal loop divided longitudinally; paranal cell divided longitudinally; five terminal cells between RP and MA; five terminal cells between MP and $\mathrm{CuA}$; and obtuse angle between PsA and CuP+AA. Burmagomphid

dragonflies were represented so far only by one specimen from the middle Cretaceous of Southeast Asia. This new record extends the distribution to Patagonia, to the Cenozoic, and also to paleolake deposits.

Julián F. Petrulevičius [levicius@fcnym.unlp.edu.ar], CONICET and División Paleozoología Invertebrados, Facultad de Ciencias Naturales y Museo, Universidad Nacional de La Plata, Paseo del Bosque s/n, La Plata (1900), Argentina.

This is an open-access article distributed under the terms of the Creative Commons Attribution License (for details please see creativecommons.org), which permits unrestricted use, distribution, and reproduction in any medium, provided the original author and source are credited. 